\title{
掻痒性皮膚疾患の外用療法と薬局薬剤師の役割
}

\author{
山浦克典
}

\section{Topical Treatment of Pruritic Skin Disease and the Role of Community Pharmacists}

\author{
Katsunori Yamaura \\ Faculty of Pharmacy, Keio University; 1-5-30 Shibakoen, Minato-ku, Tokyo 105-8512, Japan.
}

(Received July 9, 2019)

\begin{abstract}
Itching, or pruritus, can be defined as an unpleasant sensation that evokes the desire to scratch. Pruritus is most commonly associated with a primary skin disorder such as atopic dermatitis (AD), psoriasis, etc., and can have a major impact on the quality of life of those patients. Itch-induced scratching can further damage the skin barrier, leading to a worsening of symptoms. For that reason, it is important to manage pruritus. Topical glucocorticoids are commonly the first-line therapy in the management of $\mathrm{AD}$ and psoriasis patients. We found that topical glucocorticoids induce pruritus in mice under certain conditions. Topical glucocorticoids may induce pruritus in a mouse model of allergic contact dermatitis via inhibition of prostaglandin $(\mathrm{PG}) \mathrm{D}_{2}$ production in antigen-mediated activated mast cells in the skin. Additionally, topical glucocorticoids do not induce pruritus in healthy skin. These results indicate the importance of controlling skin inflammation to a healthy level by applying sufficient quantities of glucocorticoids to avoid glucocorticoid-induced pruritus. However, topical "steroid phobia" is common in Japan, and most patients apply inadequate amounts of topical glucocorticoids for this reason. This may cause glucocorticoid-induced pruritus in patients by prolonging the skin inflammation. We conducted a survey regarding community pharmacists' instructions on the application quantity of topical glucocorticoids and found that most community pharmacists have experienced inappropriate instructions concerning this point.
\end{abstract}

Key words_— pruritus; topical steroid; prostaglandin $\mathrm{D}_{2}$; pharmacist; fingertip unit

\section{はじめに}

掻痒は「掻破したい欲求をかきたてる不快な感覚」 と定義され，多くの人が経験するありふれた症状で あるが，アトピ一性皮膚炎を始め多くの皮膚疾患の 主要な愁訴でもある。本来掻痒は，掻き動作の誘発 により皮膚表面や表層に存在する異物を除去する生 体防御感覚の 1 つであるが，長く続く強い掻痒は集 中力の低下や睡眠障害を招き, 患者の QOL を著し く損なう。1)掻痒は QOL を低下させるだけでな く, 掻破による皮膚バリア機能の破壊が炎症を悪化 させ，掻痒と掻破の悪循環（itch-scratch cycle）を 惹起する。そのため皮膚疾患の治療成績向上の観点 からも掻痒のコントロールは重要である. ${ }^{2)}$ ステロ イド外用薬はアトピー性皮膚炎や乾癬等の慢性掻痒

慶應義塾大学薬学部（干105-8512 東京都港区芝公園 15-30)

e-mail: yamaura-kt@ keio.jp

本総説は, 日本薬学会第 139 年会シンポジウム S32 で 発表した内容を中心に記述したものである.
性皮膚疾患の第一選択薬であり，慢性皮膚疾患の治 療においては，しばしば長期にわたり使用される. 外用ステロイドは局所での抗炎症作用の強さや全身 性の副作用の少なさが利点であるが，一方で長期間 の使用に伴い，皮膚萎縮や感染防御能の低下を招 く．ステロイド外用薬は掻痒の軽減を期待して処方 されてもいるが，抗掻痒作用に関する明確なエビデ ンスはない.さらに，ステロイド外用薬の添付文書 に，副作用として「掻痒」を挙げる品目もある．わ が国のアトピー性皮膚炎診療ガイドライン3)に掲載 されるステロイド外用薬 23 成分中 14 成分の添付文 書の副作用項目に「掻痒」が記載されている（Table 1)。また，アトピー性皮膚炎や接触皮膚炎，乾 癬, 湿疹梯皮膚炎の患者にステロイド外用療法を施 行した際，長期使用に伴う副作用の約 4 分の 1 が掻 痒の訴えであったとの報告がなされている. ${ }^{4)}$ そこ で，ステロイド外用薬の長期使用と掻痒との関係を マウス皮膚炎モデルにステロイド外用薬を長期間塗 布するモデルを作製して検討した．さらに，実臨床 
Table 1. Presence of Adverse Events of Itching in the Package Insert and Rank of Topical Corticosteroids

\begin{tabular}{ll}
\hline \hline Rank of topical corticosteroids & $\begin{array}{r}\text { Adverse events } \\
\text { of itching in the } \\
\text { package insert }\end{array}$ \\
\hline Strongest & $\bigcirc$ \\
$0.05 \%$ clobetasol propionate & $\bigcirc$ \\
$0.05 \%$ diflorasone diacetate & \\
\hline Very strong & $\bigcirc$ \\
$0.1 \%$ mometasone furoate & $\bigcirc$ \\
$0.05 \%$ betamethasone butyrate propionate & \\
$0.05 \%$ fluocinonide & \\
$0.064 \%$ betamethasone dipropionate & \\
$0.05 \%$ difluprednate & \\
$0.1 \%$ amcinonide & \\
$0.1 \%$ diflucortolone valerate & \\
$0.1 \%$ hydrocortisone butyrate propionate & \\
\hline Strong & \\
$0.3 \%$ deprodone propionate & $\bigcirc$ \\
$0.1 \%$ dexamethasone propionate & \\
$0.12 \%$ dexamethasone valerate & \\
$0.1 \%$ halcinonide & \\
$0.12 \%$ betamethasone valerate & \\
$0.025 \%$ fluocinolone acetonide & \\
\hline Medium & \\
$0.3 \%$ prednisolone valerate acetate & \\
$0.1 \%$ triamcinolone acetonide & \\
$0.1 \%$ alclometasone dipropionate & \\
$0.05 \%$ clobetasone butyrate & \\
$0.1 \%$ hydrocortisone butyrate & \\
$0.1 \%$ dexamethasone & \\
\hline Weak & \\
$0.5 \%$ prednisolone & \\
\hline
\end{tabular}

ではステロイド外用薬の適切な量を適切な期間塗布 することが治療上不可欠であるが，患者への使用方 法の指導の責任は多くの場合，薬局薬剤師が担って いる。 そこで，薬局薬剤師を対象にステロイド外用 薬の服薬指導の内容, 特に塗布量に関する指導実態 について調査した。

\section{ステロイド外用薬の長期使用による掻痒の誘発}

近年，マウスの急性皮膚炎モデルに対する外用ス テロイドの適用が, 痒み因子であるサブスタンス $\mathrm{P}$ や神経成長因子を増加させ，掻痒を悪化させること が報告されている.5,6) しかし，これらの報告は短期 モデルでの現象であり，臨床で問題となっている慢 性皮膚炎を模倣したモデルに対し長期間ステロイド 外用薬を使用した際の搔痒に対する影響の報告はな

い.そこでわれわれは，慢性皮膚炎モデルとしてマ ウスにハプテンを週 3 回反復塗布して慢性接触皮膚 炎モデルを作製し, ${ }^{7-9)}$ 当該マウスに長期間ステロ イド外用薬を塗布した際の掻痒に対する影響を検討 した. ${ }^{10)}$ デキサメタゾン群は，皮膚炎の指標である 耳介腫脹を試験期間を通じて有意に改善したが，痒 みの指標である掻破回数は塗布期間に従い悪化し, 試験終了時には対照群と比較して有意に増悪した. この結果から，長期間のステロイド塗布が皮膚炎を 抑制する一方，掻痒を悪化させることを明らかにし た．そこで，ステロイド外用誘発掻痒とステロイド 外用薬の効力ランクの関係をべタメタゾン吉草酸エ ステル (strong)，デキサメタゾン (medium) 及び プレドニゾロン（weak）を用い検討したところ， 各ステロイドのランクに応じた皮膚炎抑制効果が得 られたものの，掻痒はステロイドのランクに関係な く増悪したことから，本掻痒はステロイド外用薬の ランクに影響しないステロイド普遍的な現象である ことが示唆された。

さらに，ステロイド外用誘発掻痒は，正常皮膚マ ウスには生じないことから, ${ }^{11)}$ 慢性皮膚炎状態にス テロイド外用薬を適用する場合にのみ誘発され，ス テロイド外用薬そのものが起痒剤ではないことを明 らかにした (Fig. 1).

われわれは，ステロイド外用誘発掻痒のメカニズ ムとして，ステロイド外用薬が“内因性抗掻痒因子” の産生を抑制して間接的に掻痒を増悪すると考え, この内因性抗掻痒因子の候補としてプロスタグラン ジン（prostaglandin; PG） $\mathrm{D}_{2}$ を挙げた． $\mathrm{PGD}_{2}$ は アラキドン酸の代謝物の 1 つで, 皮膚においてはマ ス卜細胞が主要な $\mathrm{PGD}_{2}$ 産生細胞であるととも に，マス卜細胞の脱顆粒を抑制して抗掻痒作用を示 すことが多く報告されている. ${ }^{12-14)}$ アラキドン酸は シクロオキシゲナーゼ (cyclooxygenase; COX) に より $\mathrm{PG}$ へと代謝されるが，ステロイドの COX 抑

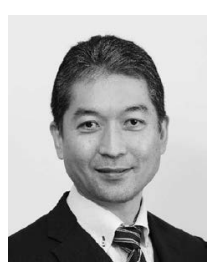

山浦克典
慶應義塾大学薬学部医療薬学社会連携 センター社会薬学部門 教授・附属薬局 長. 千葉大学薬学部卒, 同大学院博士 課程修了。(株) ツムラ研究所研究員, 保険薬局薬剂師（東京・埼玉・茨城）, (株) 富士バイオメディックス臨床開発 モニター, 千葉大学大学院薬学研究院 講師, 同准教授を経て平成 27 年より現 職. 


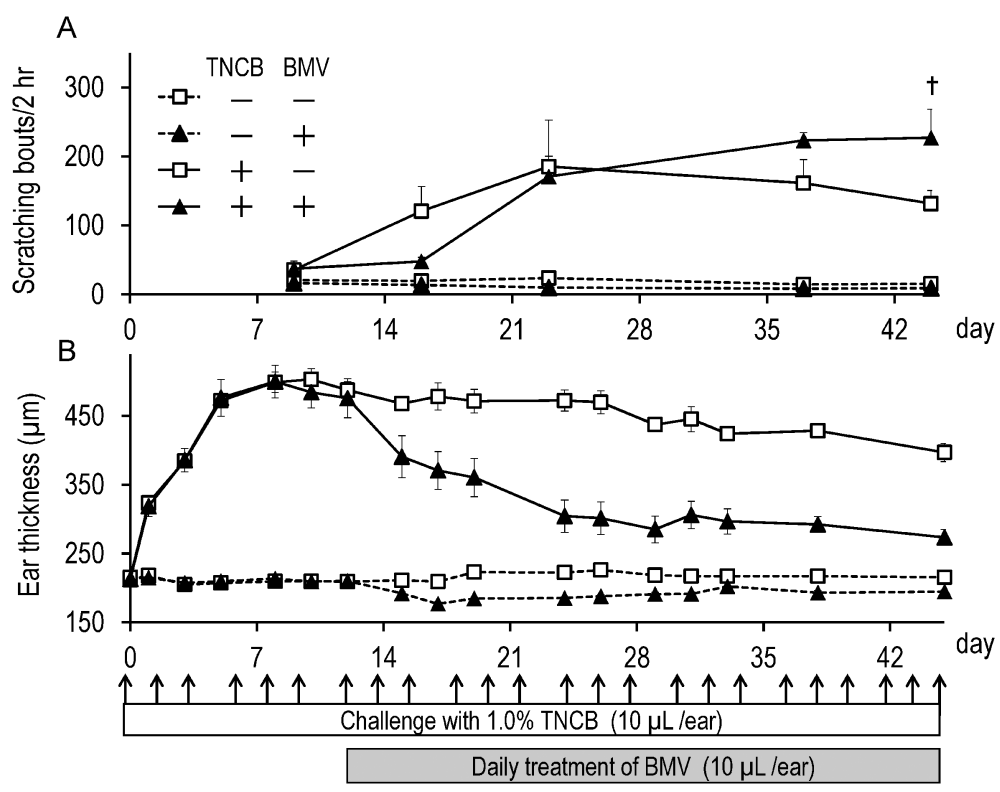

Fig. 1. Effects of Topical 0.01\% Betamethasone Valerate (BMV) on Scratching Behavior and Ear Thickness in Healthy C57BL/6 Mice

BMV was applied topically every day from day 14 to 45 . (A) Immediately after the 2,4,6-trinitro-1-chlorobenzene (TNCB) challenge, scratching bouts were counted for $2 \mathrm{~h}$. (B) Ear thickness was measured $24 \mathrm{~h}$ after TNCB challenge. Values represent the mean \pm S.E. for $5-6$ mice. ${ }^{\dagger} p<0.05 v s$. $\mathrm{TNCB}^{+} / \mathrm{BMV}^{-} \mathrm{mice}^{-}$ (Tukey-Kramer method).

制作用により， $\mathrm{PGD}_{2}$ 産生も抑制すると考えた。検 討の結果，皮膚炎対照群では病変組織中の $\mathrm{PGD}_{2}$ 量が正常皮膚マウスに比べ高值を示したが，ステロ イド塗布群では正常皮膚マウスレベルまで低下し た. ${ }^{11)} さ ら に ， R B L-2 H 3$ 細胞の脱顆粒試験系を用 いて，特異抗原刺激に伴う $\mathrm{PGD}_{2}$ 産生に対するス テロイドの直接作用を検討したところ，ベタメタゾ ン吉草酸エステル，デキサメタゾン及びプレドニゾ ロンのいずれも有意に $\mathrm{PGD}_{2}$ 産生を抑制した。皮 膚炎対照群の病変組織では, $\mathrm{PGD}_{2}$ 産生が充進し掻 痒を抑制性に調節していると推測される結果を併せ 考えると，ステロイドによる皮膚マスト細胞の $\mathrm{PGD}_{2}$ 産生抑制がステロイド外用誘発掻痒の機序の 1 つと考えられた。また，正常皮膚においては外用 ステロイドによる掻痒は誘発されないことから，ス テロイド外用薬の適正使用により皮膚の炎症状態を 正常レベルにコントロールすることが重要と考えら れた。

薬局薬剤師によるステロイド外用薬の塗布量の指 導を通じた適正使用推進 ${ }^{15)}$

皮膚の炎症状態を正常レベルにコントロールする には，外用ステロイドの適量塗布が重要となるが, ステロイド外用薬に対する不安や恐怖心から，ステ ロイド外用薬の使用を無断で中断したり，実際の塗
布量及び塗布回数を自己判断で減らしてしまうステ ロイド恐怖症の患者数は非常に多く，アトピー性皮 膚炎患者の $80.7 \%$ がステロイド外用薬に対して恐 怖を抱いているとの報告もある. ${ }^{16)}$ 恐怖心がアドヒ アランス低下を引き起こし, 不足量のステロイド塗 布を継続すると，患部炎症が遷延化し，結果的にス テロイド外用薬の長期使用につながりかねない。そ の結果，前述のマウスを用いた研究結果と同様のス テロイド外用薬誘発掻痒が，ヒトにおいても誘発さ れる可能性は否定できない。そこで，患者自身が処 方されたステロイド外用薬の適切な塗布量を患部に 適用することが重要となる.

アトピー性皮膚炎診療ガイドラインによると，ス テロイド外用薬の塗布量は finger tip unit (FTU) を目安にするとされる. ${ }^{3)}$ ところが近年，ガイドラ インを逸脱したステロイド外用薬の塗布指導が非専 門医により広く行われている実態が報告され た. ${ }^{17,18)}$ 一方，医薬品の服薬指導は薬剤師において も法的義務がある上，近年外用薬の塗布に関し薬剤 師の実技指導が認められ，外用薬指導の重要性はま すます高まっている. ${ }^{19)}$ 病院及び薬局薬剤師の外用 薬指導の内容を調査した研究では，薬剤師がステロ イド外用薬の塗布部位，回数及びタイミングを重視 して指導していること，ガイドラインを知っている 
薬剤師が指導内容を工夫していることが報告されて いるが, ${ }^{20)}$ 薬局薬剤師におけるステロイド外用薬の 塗布量に関する指導実態の詳細は不明である。 そこ で薬局薬剤師を対象にステロイド外用薬の服薬指導 の中で特に塗布量に注目し，ガイドラインが推奨す るFTU を用いた指導，及び “薄く延ばして塗布” というガイドラインを逸脱した服薬指導実態の詳細 を明らかにすることを目的に調査研究を実施し た. ${ }^{15)}$ 本研究により, ステロイド外用薬の塗布量を FTU を用いて適切に指導する薬局薬剤師の特性を 明らかにし，適正使用の推進に貢献できると考えた。

われわれの研究により， $80.3 \%$ の薬剤師が過去に ガイドラインを逸脱した “薄く延ばして塗布”する 指導経験があることが判明した。 また，現在でも日 常業務で “薄く延ばして塗布”する指導をしている 薬剤師が $20.3 \%$ にんだ。さらに，“薄く延ばして 塗布”する指導をした理由として，正しい方法との 誤認や先輩薬剤師による指導など，明らかな根拠の ないものが $66.4 \%$ を占めた.

一方，ガイドラインが推奨する FTU の認知度は 65.3\%だったが，実際にFTU を使って塗布量を指 導している薬局薬剤師は $35.7 \%$ に留まった。クロ ス集計の結果，ガイドラインの閲覧経験のある薬剤 師ほど，FTU を使って適切に塗布量に関する服薬 指導を行い，薬剂師の職能を果たしていることが示 唆された.

また, 塗布量の説明を一切行わない薬剤師は $32.7 \%$ 存在したが，ガイドラインに関連する知識不 足がその一因と考えられた。

\section{おわりに}

ステロイド外用薬の漫然とした不適切な長期使用 は，マスト細胞の $\mathrm{PGD}_{2}$ 産生を抑制し，その結果， $\mathrm{PGD}_{2}$ による脱顆粒抑制作用が減弱することで，炎 症状態の皮膚においてマスト細胞の脱顆粒が充進 し，掻痒を増悪する可能性が示唆された。 また，正 常な皮膚のマウスにステロイド誘発掻痒が起きない ことから，ステロイド外用薬を適正使用し，皮膚炎 の皮膚状態を適切にコントロールすることが，ステ ロイド掻痒の誘発防止に重要であると考えられた。 臨床において，ステロイド外用薬の不十分量の塗布 は，皮膚炎の遷延化を引き起こし，不適切な長期使 用につながることから長期ステロイド誘発掻痒を引 き起こす懸念がある。これを防止するうえで，薬局
薬剤師がステロイド外用薬の服薬指導において，適 切な塗布量を指導することが重要となる，ガイドラ インを参照し理解している薬局薬剤師ほどステロイ ド外用薬の塗布量の適切な服薬指導を実践し，職能 を発揮していることから，塗布量を含めた適切な服 薬指導の推進にガイドライン閲覧の啓発が有効な手 段の 1 つと考えられた.

謝辞 基礎研究は土居亮介学士, 船越彩花学 土，調査研究は渡辺瑠五学士，大石信雄博士の協力 の下に行われた。ここに感謝の意を表す。

\section{利益相反＼cjkstart開示すべき利益相反はない.}

\section{REFERENCES}

1) Kiebert G., Sorensen S. V., Revicki D., Fagan S. C., Doyle J. J., Cohen J., Fivenson D., Int. J. Dermatol., 41, 151-158 (2002).

2) Grillo M., Long R., Long D., Dermatol. Nurs., 19, 243-248 (2007).

3) Saeki H., Nakahara T., Tanaka A., Kabashima K., Sugaya M., Murota H., Ebihara T., Kataoka Y., Aihara M., Etoh T., Katoh N., Committee for Clinical Practice Guidelines for the Management of Atopic Dermatitis of Japanese Dermatological Association, J. Dermatol., 43, 1117-1145 (2016).

4) Akers W. A., Arch. Dermatol., 116, 786-788 (1980).

5) Fujii Y., Sengoku T., Takakura S., Arch. Dermatol. Res., 302, 645-652 (2010).

6) Bae S. J., Lee J. B., Takenaka M., Tanaka Y., Shimizu K., Katayama I., Exp. Dermatol., 13, 780-785 (2004).

7) Andoh T., Kuraishi Y., Nippon Yakurigaku Zasshi, 130, 386-392 (2007).

8) Ueda Y., Inoue T., Rahman M. A., Yatsuzuka R., Jiang S., Kamei C., Int. Immunopharmacol., 6, 1609-1615 (2006).

9) Inagaki N., Nagai H., J. Pharmacol. Sci., 110, 251-259 (2009).

10) Yamaura K., Doi R., Suwa E., Ueno K., $J$. Toxicol. Sci., 36, 395-401 (2011).

11) Yamaura K., Doi R., Suwa E., Ueno K., J. Toxicol. Sci., 37, 1127-1134 (2012).

12) Arai I., Takano N., Hashimoto Y., Futaki N., 
Sugimoto M., Takahashi N., Inoue T., Nakaike S., Eur. J. Pharmacol., 505, 229-235 (2004).

13) Honma Y., Arai I., Hashimoto Y., Futaki N., Sugimoto M., Tanaka M., Nakaike S., Eur. J. Pharmacol., 518, 56-62 (2005).

14) Hashimoto Y., Arai I., Tanaka M., Nakaike S., J. Pharmacol. Sci., 98, 90-93 (2005) .

15) Oishi N., Iwata H., Kobayashi N., Fujimoto K., Yamaura K., Drug Discov. Ther., 13, 128132 (2019).

16) Aubert-Wastiaux H., Moret L., Le Rhun A., Fontenoy A. M., Nguyen J. M., Leux C., Misery L., Young P., Chastaing M., Danou N., Lombrail P., Boralevi F., Lacour J. P., Mazereeuw-Hautier J., Stalder J. F., Barbarot S., Br. J. Dermatol., 165, 808-814 (2011).
17) “Allergy Shikkan Taisaku no Kintenka nikansuru Kenkyu.”〈http://www.fukushihoken. metro.tokyo.jp/kankyo/kankyo_eisei/senmon iinkai / allergyiinkai.files / 29 _ 2allergyiinkai. sankoushiryou2.pdf $\rangle$, Bureau of Social Welfare and Public Health, Tokyo Metropolitan Govemment Web, cited 9 June, 2019.

18) QLifePro. "Research report": $\langle$ http://reports. qlifepro.com/allergy2014/dermatitis/ $>$, cited 9 June, 2019.

19) Ministry of Heath, Labour and Welfare: 〈https://www.mhlw.go.jp/file/06-Seisakujou hou-11120000-Iyakushokuhinkyoku/02_4.pdf $\rangle$, cited 9 June, 2019.

20) Kaneko S., Kakamu T., Matsuo H., Naora K., Morita E., Jpn. J. Allergol., 63, 1250-1257 (2014). 